\title{
Moderne Semantiek en Formele Homiletiek
}

\author{
A G van Aarde
}

\section{Inleiding}

Dit was James Barr wat met sy "The Semantics of Biblical Language"1 in 1961 daarop gewys het dat die belang van die linguistiek vir die teologie vanselfsprekend is. Die Bybel is nou eenmaal geskrewe taal. Hoewel Barr se boek nie in alle kringe op dieselfde wyse ontvang is nie, was die belangrikste bydrae vir die beoefening van Bybelse teologie sekerlik om te waarsku "against premature theological evaluations of biblical linguistic data". ${ }^{2}$ Bybelse teologie is grootliks afhanklik van die verstaan van die tale van die Bybel. In die lig van die resente ontwikkeling op die gebied van die algemene linguistiek is dit 'n bewering wat nie ligtelik opgeneem kan word nie. Die bevindings van die moderne linguistiek het belangrike implikasies vir verskillende aspekte van Bybelnavorsing. ${ }^{3}$ Die teologie het vir' $n$ tyd lank nie van hierdie bevindinge kennis geneem nie. Sedert Barr se epog-makende boek het daar egter 'n veranderde situasie ingetree. Verskeie pogings is aangewend om die resultate van die moderne linguistiek vir die teologie vrugbaar te maak. Dit is pogings wat wissel van die strukturale analise van die Franse tot die Amerikaanse "literary criticism," die "Generative Poetik" van Erhardt Güttgemanns in Bonn en die redevoeringsanalise van die Suid-Afrikaanse en Amerikaanse vakmanne. ${ }^{4} \mathrm{Al}$ hierdie pogings het dit in gemeen, naamlik dat dit gebaseer is op die insigte van die nuwere taal - en literatuurwetenskap. Hier te lande geniet dit tans wye belangstelling, hoewel nie op dieselfde vlak nie as byvoorbeeld Güttgemanns se werkgroep "Theologie und Linguistik" wat sedert November 1970 deur sy tydskrif Linguistica Biblica aangevul word. ${ }^{5}$ So is daar onder andere die dissertasies van W S Vorster ${ }^{6}$ en J A Loader ${ }^{7}$ bekend, en bestaan daar ook 'n sub-werkgroep van die Nuwe Testamentiese Werksgemeenskap van Suid-Afrika wat onder andere die bydrae van die algemene linguistiek vir die Nuwe Testamentiese Wetenskap ondersoek. ${ }^{8}$ Verskeie inleidende artikels in Suid-Afrikaanse teologiese tydskrifte, ${ }^{9}$ asook die belangrike publikasie van die doyen van die Suid-Afrikaanse vakmanne, J P Louw, Semantiek van Nuwe Testamentiese Grieks, ${ }^{10}$ het al baie hiermee meegehelp. Skrywer is egter nie bewus van' $n$ publikasie wat die bydrae van die moderne linguistiek vir die homiletiek verdiskonteer het nie, behalwe 'n paar Duitse artikels op die patroon van Güttgemanns se "Generative Poetik," soos byvoorbeeld die van Folker Siegert in die reeds genoemde Linguistica Biblica met die titel, Narrative Analyse als Hilfe zur Predigtworbereitung 
- ein Beispiel. ${ }^{11}$ ' $n$ Poging sal met hierdie studie aangewend word om op die patroon van die Suid-Afrikaanse en Amerikaanse redevoeringsanalitiese metode, die bydrae van 'n vertakking van die moderne linguistiek, te wete die moderne semantiek, vir enkele aspekte van die metode en vorm van die formele homiletiek aan te toon. Skrywer wil hom egter hoegenaamd nie uitgee as 'n kenner op die gebied van die homiletiek nie. Die belangrikste doelwit van hierdie studie is dus om aan te toon wat moderne semantiek inleidend en oorsigtelik behels en dat dit vir die homiletiek van groot betekenis kan wees.

\section{Semantiek is 'n vertakking van die linguistiek}

Linguistiek is die wetenskap wat hom besig hou met die verskynsel taal. Wat is taal? Afrikaans, Grieks en Hebreeus is voorbeelde van taal. Hiermee is egter nie gesê wat taal is nie. Taal is ' $n$ tekensisteem wat vir kommunikasie gebruik word, en wat van ander kommunikasiesisteme (byvoorbeeld 'n morsekode of 'n flits van inligting met behulp van spieëls wat ook tekensisteme is) onderskei word deur sy eie konvensionele tekens, naamlik woorde en sinne wat mondelings by wyse van bepaalde klankvorme geuit word, of skriftelik vergestalt word met tekens wat dit simboliseer. ${ }^{12}$ Die verskynsel taal kom dus op ' $n$ sosiale en individuele vlak tot uiting, en dit is taal in die praktyk. Op'n sosiale vlak is dit 'n sisteem van tekens wat 'n bepaalde gemeenskap aanwend om met bepaalde klankvorme kommunikasie te bewerkstellig. Dit word aangedui met die tegniese term la langue (= ' $n$ taal). Die uiting op individuele vlak is eintlik die werklike aanwending van ' $n$ taal, naamlik taalgebruik, en word aangedui met die tegniese term la parole. Dit is die werklike gebruik op ' $n$ bepaalde moment deur' $n$ bepaalde persoon. ${ }^{13}$ Die linguistiek wil alles wat met die verskynsel taal, ' $n$ taal en taalgebruik in verband staan, beskryf, ontleed en in sisteem bring sodat die kennis wat verkry word tot juister kommunikasie kan dien - sowel om die taal beter te hanteer, maar ook om die interpretasie van gesproke of geskrewe taal te verskerp. ${ }^{14}$ Hierdie onderskeidinge tussen die verskynsel taal (= le langage).' $n$ taal (= la langue) en taalgebruik (= la parole) is te danke aan die baanbreker van die moderne linguistiek, Ferdinand de Saussure, ${ }^{15}$ en het vanaf ongeveer die dertiger jare van die twintigste eeu een van die belangrikste basisse van die moderne linguistiek geword.

Die vernaamste breuk met die ouere linguistiek in sy beoefening van geskrewe taal is sekerlik die onderskeiding tussen diachroniese en sinchroniese metodologiese fasette van ondersoek. Hierdie onderskeiding is ook aan De Saussure te danke. Die diachroniese het te doen met die historiese gang van taalelemente, dit wil sê die veranderinge wat ' $n$ taal oor' $n$ lang tydperk heen ondergaan het. Die 
sinchroniese het te doen met die stand van sake in ' $n$ bepaalde tydvak. Dit wil byvoorbeeld die gebruik van die taal binne ' $n$ bepaalde periode beskryf en verklaar om sodoende 'n beeld te gee van die struktuur van die taal en sy elemente. Dit wil dus probeer aandui hoe hulle in mekaar pas en ten opsigte van mekaar figureer. ${ }^{16}$ Die ouere linguistiek het hom feitlik deurgaans tot die historiese beperk, terwyl die moderne linguistiek die klem op die sinchroniese laat val. Die sinchroniese linguistiek bied die materiaal waarmee die diachroniese gebou moet word, en nie andersom nie. Omgekeerd het die sinchroniese wel die historiese materiaal nodig om verskynsels behoorlik te verklaar. Dit was'n gebrek by die ouere linguistiek dat die uitgangspunt hoofsaaklik net die historiese was. ${ }^{17}$

Sedert De Saussure word die strukturele metode van taalstudie (wat in skerp teenstelling staan met die benadering van die ouere linguistiek) die basis van die moderne linguistiek. Die strukturele metode van taalstudie vra na sintese en soek na die samehang en struktuur van taalelemente. ${ }^{18}$ Dit het die tydvak van die strukturalisme in die linguistiek tot gevolg gehad, ${ }^{19}$ en uiteindelik tot 'n heel nuwe metode van taalkundige ondersoek gelei. Hierin is Noam Chomsky die leidende figuur. Hierdie benadering staan bekend as die Transformasioneel-Generatiewe Grammatika (TGG). ${ }^{20}$ Sedert die publikasie van Chomsky se Syntactic Structures in 1957 het die TGG algemene aanklank in die linguistiek gekry, en is dit vandag 'n saak van konsensus dat taal alleen op ' $n$ transformasioneel-generatiewe model beskryf kan word. Verskeie sub-rigtings en interpretasies het binne die hoofstroom van die TGG ontwikkel. Die sogenaamde standaardteorie gaan uit van drie komponente in 'n grammatika, naamlik ' $n$ sintaktiese, 'n semantiese en ' $n$ fonologiese. Die sintaktiese komponent bestaan weer uit ' $n$ basis - subkomponent/en 'n transformasionele subkomponent. ${ }^{21} \mathrm{~J}$ A Loader beskryf dit verder soos volg: "In die basis word dieptestrukture gegenereer, dit wil sê basiese gedagtes word hier in grondliggende taalstrukture verwerk. Hierdie dieptestrukture word deur die transformasionele subkomponent in oppervlaktestrukture getransformeer, dit wil sê omgesit in verskyningsvorms. Die semantiese komponent werk in op die dieptestrukture sodat die sin 'n semantiese representasie verkry, en die fonologiese komponent werk in op die oppervlaktestrukture sodat die sin 'n fonologiese representasie bekom, dit wil sê in aktuele klanke verskyn. Hoewel die TGG nie dieselfde is as die strukturalisme wat hom in die linguistiek voorafgegaan het nie, is hy basies struktureel. Grondliggende gedagtes, die bedoeling-van die taalgebruiker, die begrip (designatum) wat hy van'n saak (denotatum) het, word omgesit nie in enkele woorde en geisoleerde morfeme nie, maar in betekenisdraende woordrelasies, naamlik die sin." ${ }^{22}$

Die linguistiese bestudering van die elemente van taal geskied tradisioneel aan die hand van 'n aantal vertakkings waarin die linguis- 
tiek gerieflikheidshalwe verdeel, naamlik klankleer, woordleer, sinsleer en stylleer. Semantiek is op sy beurt weer 'n vertakking van die tradisionele woordleer. ${ }^{23}$ Tradisioneel is semantiek die wetenskap wat hom besig hou met die betekenisleer van woorde van 'n taal, en wat ook aandag gee aan die betekenis veranderinge van woorde. ${ }^{24}$ Dit was die gevolg daarvan dat daar in die semantiese nadenke van die oudheid gereken is dat betekenis ' $n$ inherente besit van ' $n$ woord is. Etimologie van 'n woord is as belangrik beskou om die werklike betekenis (Grundbedeutung) van 'n woord vas te stel. Volgens die moderne semantiek dra hierdie etimologiese benadering weinig of niks by tot die vasstelling van betekenis in 'n bepaalde konteks nie. Die enigste nut is meestal dat dit die ondersoeker in staat stel om te weet watter betekenis-veranderinge ' $n$ woord ondergaan het. ${ }^{25}$ Die onderskeid tussen sichronie en diachronie is daarom een van die ingrypendste insigte van die moderne linguistiek vir die semantiek. In die moderne semantiek val etimologie daarom heettemal buite die gesigsveld, en moet etimologie en semantiek volgens J H Hospers ${ }^{26}$ as twee afsonderlike aspekte van die wetenskaplike bestudering van woordleer beskou word. Eersgenoemde as vormleer en laasgenoemde as betekenisleer. Dit is ' $n$ breuk met die tradisionele benadering. ${ }^{27}$

\section{Moderne semantiek is basies struktureel}

Die moderne semantiek is ' $n$ betekenisleer wat uit die strukturele benadering van taal voortgevloei het. Met die konteks word deeglik rekening gehou. Die onmiddellike konteks waarin 'n woord gebruik word, is bepalend vir die aktuele betekenis van die woord. Betekenis word verkry uit die groepsinhoud van woorde, die sin, die perikoop, die hoofstuk, die hele boek. Woorde, sinne, perikope en groter eenhede word deur die spreker of outeur in bepaalde relasies (struktuur) tot mekaar gebruik om so betekenis en derhalwe kommunikasie moontlik te maak. Om die betekenis van ' $n$ bepaalde woord in ' $n$ bepaalde konteks na te vors, asook die skopus van 'n bepaalde geskrewe stuk taal, moet die struktuur van die groepsinhoud van die woorde, die sinne en die perikope by wyse van gesonde linguistiese reëls vasgestel word. "This structuring may be striking or unnoticed, deliberate or spontaneous, firm or loose, successful or less successful, yet structuring remains an irrefutable fact, whether at a word or sentence or more comprehensive level." En verder: "Structuring as a rule is done practically without being conscious of it. It may nevertheless also be a process consciously executed. This conscious structuring, which may also be called stylisation, is peculiar to all languages. Regarding the Greeks with their strong literary tradition and their sense for logic and beauty of form, we may well conceive that we shall find not only spontaneous structuring, but also purposeful 
structuring. ${ }^{\prime 28}$ Die argument dat ' $n$ vasstelling van 'n fyn-gekomponeerde struktuur van 'n stuk taal ' $n$ bewys is dat strukturele semantiese nadenke kunsmatig en geforseerd is, en derhalwe aan betroubaarheid moet inboet, gaan in die lig van die voorafgaande nie op nie.

Die moderne semantiek wil dus transformasionele arbeid verrig. Eerstens wil dit-die-struktuur van die oppervlakte bepaal en uitgaande daarvan deurdring tot die dieptestruktuur. 'n Belangrike nut van ' $n$ analisering van die oppervlaktestruktuur is om vas te stel waarom die outeur gereken het dat die bepaalde oppervlakte die beste representasie van die grondliggende dieptestruktuur is. Die manier hoe dit gesê word, is deel van die semantiese ${ }^{29}$ Hierdie transformasionele arbeid is ' $n$ ingewikkelde proses, maar eers is dit nodig om na enkele belangrike basiese beginsels van die moderne semantiek te kyk.

Daar is reeds op gewys dat betekenis nie inherent in ' $n$ woord geleë is nie. Woorde het nie betekenis nie, maar dien vir ' $n$ betekenis. Die betekenis waarvoor ' $n$ bepaalde woord dien, word uit die konteks bepaal. Dit sluit in dat betekenis bepaal word uit die groepsinhoud van woorde en die relasies van sinne, perikope en groter eenhede. Dit is radikaal anders as die tradisionele semantiese benadering wat meestal van ' $n$ logosentriese of atomistiese standpunt uitgegaan het. In sò 'n benadering is gereken dat daar vir ' $n$ woord 'n Grundbedeutung bestaan wat dan vir die betekenis van die aktuele gebruiksgeval bepalend sou wees. Barr noem dit "root fallacy." Hy veroordeel dit skerp en veral ook die gebruik van hierdie werkswyse deur die Theologisches Wörterbuch zum Neuen Testament. Uitgaande van die mening dat konteks wel in berekening gebring word, is die "betekenis van 'n sin" tradisioneel dan ook dikwels bepaal deur die somtotaal van die "betekenisse" van die verskillende woorde in sò 'n $\sin$. Dit is 'n misopvatting van wat "konteks in berekening te bring" behels, en word so 'n logosentriese benaderingswyse dan ook tereg deur die moderne semantiek afgewys. 'n Uitdrukking soos "hy sal nie ou bene mak nie" het nie die betekenis van die somtotaal van die betekenisse van die verskillende woorde in die sin nie.

Die moderne semantiek is basies struktureel. Daar bestaan 'n semantiese struktuur in taal. Woorde kom in bepaalde semantiese woordvelde voor. So is daar byvoorbeeld in Grieks die woordveld van "Groups and Members of Groups," "People," "Communication," ensovoorts. Hierdie semantiese woordvelde word bepaal uitgaande van die standpunt dat daar vier basiese universele semantiese kategorieë bestaan waarin woorde verdeel kan word, naamlik objekte, gebegure, abstrakte en relasies. Die term objek verwys na dinge wat normaalweg aan gebeure deelneem soos: huis, hond, man, son, stok, water, en daarom ook hy, ek, ensovoorts. Die term gebeure dui dade, prosesse, gebeurtenisse aan soos: loop, spring, 
dans, praat, verskyn, ensovoorts. Met die term abstrakte word verwys na kwaliteite, kwantiteite of grade van objekte, gebeure of ander abstrakte. Die term relasie verwys na woorde wat as verbinding tussen woorde optree om die betekenis van hulle verhouding tot mekaar te bepaal soos: en, tot, van, deur, teen, ensovoorts. Dikwels kan twee terme tegelyk vir een woord geld, byvoorbeeld "dissipel" wat tegelyk objek en gebeure woord is (een wat leer). ${ }^{30}$ Dieselfde woord kan egter tot verskillende woordvelde behoort, juis omdat elke woord sy eie betekenisveld besit. Dit staan in die linguistiek bekend as polisemie. Dit sluit in dat een woord vir verskillende betekenisse diens kan doen. Elke woord het dus verskillende betekenismoontlikhede, of anders genoem: noempotensies. Dit is hierdie noempotensies wat tot verskillende semantiese woordvelde kan behoort. Uit die analisering van die struktuur word bepaal watter noempotensie die aktuele gebruiksgeval in 'n bepaalde konteks is. Want omdat ' $n$ woord eenmalig in ' $n$ konteks betekenis het, gebruik die taalgebruiker die toepaslike noempotensie van ' $n$ betrokke woord om in sy taalstruktuur betekenis moontlik te maak. ${ }^{31}$ Hierdie woordstudie-tegniek word komponente-analise genoem en is baie tegnies van aard. Die artikel van J H Roberts, Ekklessia in Acts - Linguistic and Theology: A Venture in Methodology, in Neotestamentica ${ }^{32}$ kan as 'n goeie voorbeeld van so 'n komponente-analise van die woord ekklēsia dien. Omdat 'n wetenskaplik-korrekte woordstudie juis so tegnies van aard is, word daar gretig uitgesien na die verskyning van die beplande "UBS New Testament Wordbook for Translators." 33 Met behulp van hierdie woordeboek sal dit in die toekoms moontlik wees om die semantiese aspek van woorde in die Nuwe Testament korrek te beskryf.

Betekenis word dus bepaal uit die struktuur. Die struktuuranalise word "discourse analysis", of "redevoeringsanalise," of "teksanalise" na aanleiding van die Duitsers se Textlinguistik" genoem, en is hoofsaaklik gerig op die perikoop as analitiese eenheid, hoewel die sin die kleinste basiese gedagtekonstruksie in taalgebruik is. Die rede waarom die teksanalise hoofsaaklik op die perikoop as analitiese eenheid gerig is, is in die aard van die perikoop self geleë. A B $\mathrm{du}$ Toit ${ }^{34}$ haal in dié verband $\mathrm{J} P$ Louw $^{35}$ aan: "A pericope has sufficient 'body' to communicate a manageable whole without losing the sense of its homogeneity ... The pericope is the largest perceptible whole, but also the smallest sensible unit of a discourse to be taken separately while still having some autonomy of its own and exhibiting its own peculiar structural pattern." Uit die aard van die saak is die objektiewe afbakening van die perikoop ' $n$ absolute vereiste. Dit word gedoen met behulp van kriteria soos onder andere herhalinge, spanninge en verskille in sinsbou en lekseemvoorkeure in bepaalde tekste. ${ }^{36}$ Hierdie perikoopafgrensing word deur die teksanalise self gekontroleer. Hier te lande kan die reeds genoemde arti- 
kels van J P Louw en A B du Toit as goeie illustrasies van die tegniek van "discourse analysis" dien. In hoofstukke 10-12 van sy boek, Semantiek van Nuwe Testamentiese Grieks, gee Louw in grade van ingewikkeldheid verdere illustrasies van die tegniek.

'n Perikoop word deur 'n outeuropgebou metsinne. ' $n$ "Sin" is nie dit wat tradisioneel tussen ' $n$ hoofletter en 'n punt staan nie. ' $n$ Sin is die kleinste gedagtekonstruksie in taal en bestaan in sy kleinste vorm uit' $n$ nominale en' $n$ verbale gedeelte. Aan beide bene kan uitbreidings plaasvind wat soms ook ingebedde sinskonstruksies bevat. So is daar basies vyf soorte kernsinne wat in alle tale voorkom, en wat maar eintlik uitbreidings is van die eerste, naamlik:

(1) die man nominale gedeelte verbale gedeelte

(2) die goeie man gee

(3) die man gee 'n boek

(4) die man gee aan hom

(5) die man gee altyd

Hierdie basiese kernsinne kan by mekaar ingebed word en steeds basies een kernsin vorm. Dit beteken dat hoewel heelwat ander kernsinne by ' $n$ bepaalde kernsin ingebed kan word, dit niks daaraan verander dat die orspronklike kernsin waarby ingebed is, die basiese kernsin bly nie. Hierdie kernsin bly dus die matrikssin en die ingebedde kernsinne is daarvan slegs inbeddinge wat bekend staan as kommata. 'n Kernsin word 'n kolon genoem, of 'n sinsegment. Die it kolon is die analitiese eenheid waarmee 'n perikoop se struktuur geanaliseer word. In Hebreeuse poësie het J A Loader aangetoon dat stichometrie in die plek van kolonmetrie in teksanalise toegepas kan word.

Die kolon word weer op sy beurt met woorde opgebou. Die tegniek om die relasies van woorde in die groepsinhoud van woorde in 'n kolon te bepaal, staan bekend as die "Immediate Constituent Analysis" (ICA). Die ICA se nadeel is dat dit met die oppervlaktestruktuur werk en dit moet derhalwe aangevul word met ' $n$ ontleding van die dieptestruktuur met behulp van die vroeër genoemde universele semantiese kategorieë, naamlik objekte, gebeure, abstrakte en relasies wat te make het met die semantiese funksies van woorde in die dieptestruktuur van ' $n$ taal. Die ICA moet egter nie as oorbodig beskou word nie, aangesien dit van groot waarde kan wees om semantiese eenhede van woordrelasies in ' $n$ kolon aan te toon. So is die relasies van die woorde "gaan loop sit" 'n semantiese eenheid in die konstruksie: Die man het gaan loop sit.

Kola staan op hulle beurt weer in relasie tot mekaar. Hierdie relasies word in die teksanalise met yerbindingslyne aangetoon. Die relasie bestaan daarin dat die een kolon die ander kolon grammaties en inhoudelik funksioneel moontlik maak. Met behulp van sulke verbindingslyne kan kolongroepe in groter perikope aangetoon word. 
Verbindingslyne wat van die reeds genoemde verbindingslyne duidelik onderskei moet word, kan ook aangebring word om byvoorbeeld herhalinge van bepaalde woorde, ensovoorts aan te toon.

Net soos verskillende kola in relasie tot mekaar staan, staan perikope, en ook groter eenhede, in relasie tot mekaar. Hierdie relasies moet in die teksanalise ook aangetoon word. In narratiewe materiaal soos byvoorbeeld in die evangelies, is perikooprelasies soms baie meer kompleks as in deskriptiewe materiaal wat byvoorbeeld in die Pauliniese briewe aangetref word.

Uit die analisering word die tema ( $=$ skopus) van die perikoop, èn van die boek in sy geheel, teruggevind. Want dit is die merkwaardige wat teksanalise uitgewys het, naamlik dat die verskillente kola in ' $n$ perikoop (en die verskillende perikope in 'n boek) om'n kern heen gebou is. Hierdie kern is niks anders nie as die eintlike ding wat die outeur wil sê, dit wil sê dit is die tema van die perikoop (of boek), of anders gesê: diesskopus. 'n Goed-geskrewe perikoop sal dus altyd 'n skopus besit, en sal daar derhalwe in elke perikoop' $n$ skopus aan te wys wees. In sommige gevalle gebruik die outeur' $n$ bepaalde kolon om die skopus van die perikoop daarin in 'n neutedop saam te vat. Hierdie één kolon neem dus die sentrale posisie tussen die ander kola in die perikoop in, dit wil sê al die ander kola draai om hierdie een kolon wat dan die wentelpunt, of beter gesê: die fokuspunt van die perikoop genoem word. Die fokuspunt kan in sommige gevalle ' $n$ kolongroep uitmaak. En in baie gevalle sal die skopus nie in ' $n$ bepaalde punt in die struktuur van die perikoop saamgevat wees nie. Dikwels sal die outeur in die gebruik van een bepaalde woord die aandag op die skopus vestig. Waar die skopus enigsins in die analisering van die oppervlaktestruktuur aan te dui is, moet dit duidelik in die teksanalise afgemerk word.

As illustrasie van die tegniek van teksanalise, en as toepassingsmateriaal in die lig van die doel van hierdie studie, word'n oorsigtelike analise van 1 Thessalonicense 4:13-18 aangebied. Die Grieks word in 'n vertaling weergegee.

\section{(a) Perikoopafbakening}

Die perikoop kan na agter afgegrens word teen hoofstuk 4:9-12, en vorentoe teen hoofstuk $5: 12 \rightarrow$. Heelwaarskynlik bestaan daar ' $n$ inhoudelike relasie tussen hierdie drie gedeeltes. Dit sal egter eers na 'n volledige analise aangetoon kan word. Vir die doel van hierdie studie bepaal ons ons egter slegs by die tersake perikoop, en dan nog by ' $n$ kleiner deel daarvan. Want die tersake gedeelte kan verder nog in twee duidelik-merkbare kleiner perikope verdeel word, naamlik 4:13-18 en 5:1-11 wat hier twee duidelike onderskeie sake binne dieselfde kader aansny. Ons werk met 4:13-18 as illustrasie. 
(b) Kolonindeling

(1) Broeders, ek wil nie hê dat julle onkundige moet wees

mbt die ontslapenes nie

met die gevolg dat julle nie treur nie soos die ander

wat nie hoop het nie

want (redegewend) as ons glo dat Jesus gesterwe het

en dat (Jesus) opgestaan het

(glo) ons sò ook

(dat) God die gestorwe Christene saam met Hom sal neem.

Heer

(2) Ja, dit sê ek met 'n woord van die Kurios day ons hoegenaamd nie die ontslapenes wat nog lewe, en derhalwe nog oor is by die parousia van die Kurios

(3) Want (verduidelikend)

(i) die Kurios self sal neerdaal vanaf die hemel met'n geroep, met die stem van die aartsengel en met (die geblaas) van die beuel van God.

(ii) en die gestorwenes in Christus sal eerste opstaan

(iii) daarna sal ons tegelykertyd saam met wat lewe, en derhalwe nog oor is

hulle (=gestorwenes) in die wolke weggevoer word die Kurios in die lug tegemoet.

(4) En so (konklusie) sal ons (en hulle) vir altyd saam met die Kurios wees.

(5) En daarom moet julle mekaar met hierdie woorde vertroos

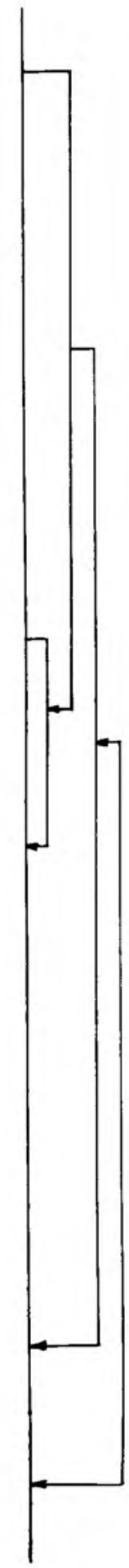


(c) "immediate constituent analysis" (Konstituente-analise)

As illustrasie word slegs die relasies van die groepsinhoud van die woorde in die apodosis van die voorwaarde-sin, (afgemerk met 'n duidelike blok) wat 'n komma van kolon een vorm, met behulp van die ICA-tegniek aangetoon, met dien verstande dat die relasies van al die woorde in die hele perikoop op dieselfde wyse aangetoon word. Die Grieks word getranskribeer.

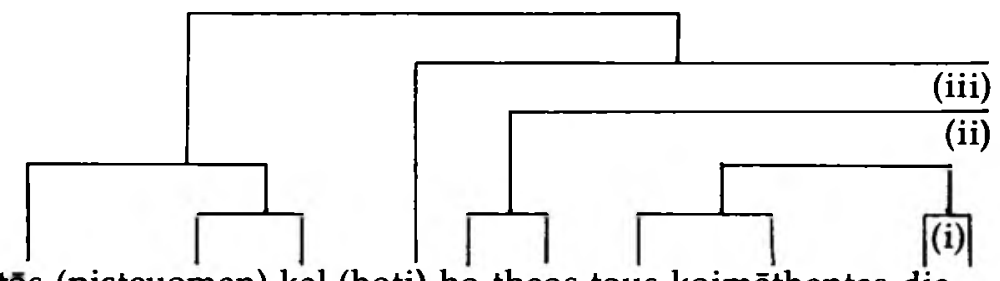

houtōs (pisteuomen) kal (hoti) ho theos tous koimēthentas dia

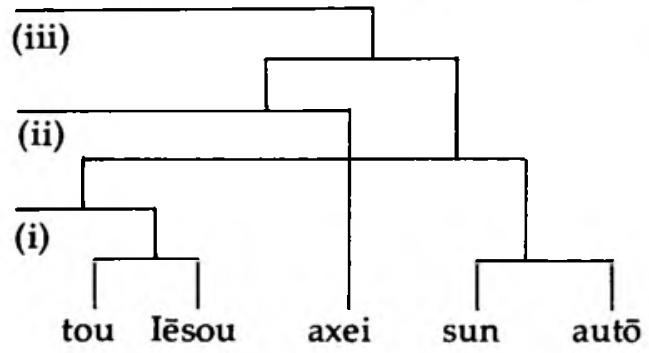

(d) Ontleding van die dieptestruktuur. ${ }^{37}$

As illustrasie word deurgedring tot die dieptestruktuur van die matrikssin van kolon twee, uitgaande van die vier basiese universele semantiese kategorieë, naamlik objekte, gebeure, abstrakte en relasies. Die Grieks word getranskribeer.

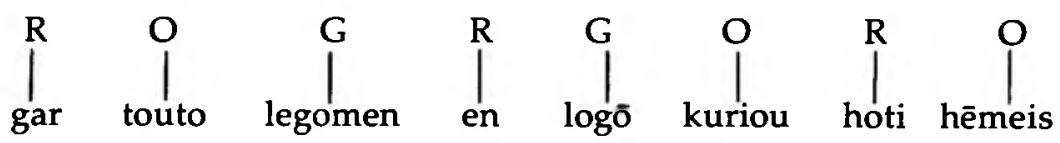

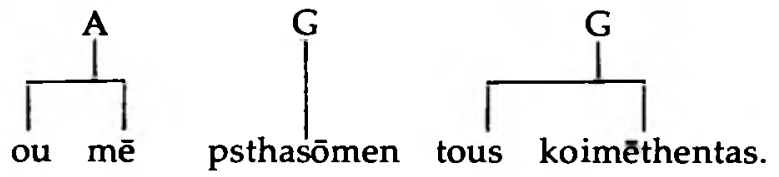

Volgens die standaardteorie van die Transformasionele Generatiewe Grammatika word grondliggende gedagtes in oppervlaktestrukture getransformeer. Op 'n omgekeerde transformasionele proses, volgens bepaalde reëls, word daar nou vanaf die oppervlaktestruktuur na die dieptestruktuur deurgedring. Nà hierdie oorsigtelike arbeid vind ons in die gestelde voorbeeld die volgende: 
(i) Die Kurios het iets gesê.

(ii) Mense het gesterf.

(iii) Paulus vertel dit wat die Kurios gesê het.

(iv) Die Kurios het gesê dat ons hoegenaamd geen voordeel bò die gestorwenes het nie.

(e) Die vasstelling van die skopus, en of daar' $n$ fokuspunt in die perikoop bestaan

Uit die teksanalise en die semantiese arbeid het dit duidelik geword dat die verskillende kola wel grammaties en inhoudelik rondom 'n sentrale tema opgebou is. Die skopus van hierdie perikoop is die bekommernis van die Thessalonicense oor die posisie van die gestorwe Christene by geleentheid van die parousia, en Paulus se troosvolle antwoord in hierdie verband. Die gestorwe Christene het net soos die gelowiges wat nog in die lewe sal wees, die hoop om altyd by die Kurios te wees. In die lig van die skopus wat so pas vasgestel is, kan die hele kolon een, en in die besonder die voorwaardesin wat 'n komma van kolon een vorm (vers 14), as die fokuspunt aangedui word.

Op so 'n wyse is 1 Thessalonicense 4:13-18 sinchronies ondersoek. Die eksegetiese arbeid is hiermee nie afgehandel nie, maar slegs begin. Die vraag na eksegese-metodologie val egter buite die bestek van hierdie studie.

\section{Moderne Semantiek en Formele Homiletiek}

Formele Homiletiek word medebepaal deur die inhoud, aard en doel van die prediking. Dit sluit in dat prediking 'n dubbele dienskarakter besit: in diens aan die gemeente moet die prediking die Woord dien. ${ }^{38}$ Soos reeds gesê, beperk ons die ondersoek by slegs enkele aspekte van die metode en vorm van die prediking, te wete die vraag na die voorbereiding van 'n preek en die vraag na die struktuur van 'n preek, en dan ook slegs fasette daarvan.

\section{Die voorbereiding van ' $n$ preek}

\section{(a) Die aanvangspunt}

J I de Wet ${ }^{39}$ wys daarop dat daar vir die homileet 'n gegewe aanvangspunt is waarvandaan hy moet uitgaan, en dit is naamlik die betrokke Bybelteks waaroor gepreek moet word. D J Booysen noem kortliks die redes waarom dit die gebruiklike metode is om juis oor 'n teks te preek. Die teks stel vir die homileet sekere grense. Hy kan dus nie sommer enige saak in die prediking te berde bring nie. Die aankondiging van ' $n$ teks vir die prediking is die belofte aan die gemeente dat die homileet die Skrif gaan uitlê. ${ }^{10}$ 
Met die term "'n teks vir die prediking" word tradisioneel 'n betrokke genommerde "teksvers" bedoel. As dit die geval is, staan die prysenswaardige belofte van die homileet om slegs net dit te spreek wat die Skrif spreek, 'n gevaar om skipbreuk te ly. Want om 'n genommerde teksvers as die vanselfsprekende aanvangspunt van die prediking te beskou, is ' $n$ atomistiese uitgangspunt wat nie met die struktuur van die betrokke Bybelgedeelte erns maak nie. ' $n$ Teksvers is nie noodwendig een gedagtekonstruksie nie, maar kan dikwels uit meer as een bestaan, of selfs uit een of meer plus 'n gedeelte van ' $n$ volgende. So vorm 1 Thessalonicense 4:16 en 'n gedeelte van vers 17 een kolon, terwyl die res van vers 17 'n volgende afsonderlike kolon vorm. Om nou 1 Thessalonicense 4:16 as die uitgangspunt van 'n stuk prediking te neem, of as die fundering van 'n bepaalde dogma, is.'n onderneming wat die gevaar loop om die konteks van die betrokke Bybelgedeelte buite rekening te laat, soos wat dit byvoorbeeld inderdaad die geval is van vraag en antwoord drie en vyftig van die Geloofsleer vir die Kategese, vanweë die Nederduitsch Hervormde Kerk van Afrika. ${ }^{41}$

Dikwels word beweer dat om ' $n$ bepaalde teksvers as aanvangspunt vir die prediking te neem, nie noodwendig 'n miskenning van die konteks hoef te impliseer nie. Die betrokke teksvers word nie uit sy verband geïsoleer nie, maar juis in die lig van die verband geīnterpreteer. Tog vind ons dit dikwels dat die homileet op 'n logosentriese wyse te werk gaan. Hy is naamlik van mening dat as hy die "betekenisse" van al die woorde in die teksvers vanuit die leksikon of kommentaar vasgestel het, en dit in 'n somtotaal hanteer, hy wel die konteks in berekening gebring het. Dit is egter 'n foutiewe hantering van "konteks".

Redevoeringsanalise het egter uitgewys dat die kleinste hanteerbare eenheid wat 'n selfstandige tema besit, ' $n$ perikoop is. Dit sal dus in die lig van die insigte van die nuwere taalkunde baie meer korrek wees om 'n bepaalde perikoop as die aanvangspunt vir die prediking te neem. En waar die tema in sommige perikope wel om 'n bepaalde kolon of kolongroep sentreer en opgebou is, kan diè betrokke kolon as die teksaankondiging vir die preek gebruik word. Dit is ' $n$ objektiewe metode wat alle willekeurigheid van die homileet uitskakel.

(b) Die keuse van die perikoop

Artikel XII van die Kerkwet van die Nederduitsch Hervormde Kerk van Afrika gee 'n paar voorskrifte vir die homileet in die Hervormde Kerk wat die keuse van die Bybelgedeelte sal bepaal waaroor hy wil preek. Met die kerklike jaar moet rekening gehou word, die Skrif moet in al sy volheid aan die gemeente uitgelê word, asook die Heidelbergse Kategismus in volgorde, en by die viering van die nag- 
maal moet voorbereidings- en dankseggingsdienste gehou word. Oor die meriete van hierdie voorskrifte wil ek my nie uitspreek nie. Die insigte van die moderne linguistiek het my egter oortuig dat sistematiek in die opvolg van preke vir die gemeente baie sinvol kan wees. Om 'n Bybelboek in volgorde, perikoop vir perikoop, in die prediking vir die gemeente uit te lê, is dus nie net sinvolle uitleg nie, maar dit het ook diè kategetiese bydrae dat die gemeente vanuit die prediking die nodige onderrig kan ontvang om self die Bybel tuis sinvol te lees en korrek in hulle eie konkrete situasie van toepassing te maak. Dit dra verder by dat' $n$ Bybelboek in sy geheel beter begryp word na die bedoeling van die Bybelskrywer self.

Die struktuur van 'n preek

(a) Die inleiding

Volgens J I de Wet ${ }^{42}$ is die doel van die inleiding om die natuurlike agtergrond waarin die gedeelte waaroor gepreek word, tuishoort, voor die gemeente op te stel - byna soos die decor by ' $n$ toneelopvoering. Met behulp van redevoeringsanalise kan die skopus van die betrokke gedeelte vasgestel word en sodoende kan daar met die inleiding van die preek gepoog word om die gemeente voor te berei tot beter verstaan van die vasgestelde skopus. Dit kan myns insiens gedoen word deur hetsy agtergrondsmateriaal aan te bied, hetsy reeds na die skopus voorlopig te verwys, of selfs deur gebruikmaking van albei hierdie elemente. So kan daar byvoorbeeld in die geval van die tersake Thessalonicense-perikoop in die inleiding verwys word na die spoedige verwagting van die parousia by die Thessalonicense èn hulle bekommernis oor die posisie van die gestorwe Christene.

(b) Die uitleg

Die uitleg van die perikoop vorm die sentrale deel van die preek. $\mathrm{J}$ I de Wet wys daarop dat die prediking nooit as ' $n$ blote herhaling of oorvertel van wat in die Bybel geskryf staan, beskou kan word nie. "Die dienskarakter van die prediking soos dit na vore gebring word deur die relatiwiteit en afhanklikheid van die prediking ten opsigte van die getuienis van die Skrif, kan die beste omskrywe word deur die prediking te tipeer as 'kommentaar op' en 'vertaling van' die Skrif." ${ }^{\prime 3}$ Hy lê elders ook klem daarop dat die gedeelte wạaroor gepreek word, onvoorwaardelik uitgelê moet word, en waarsku teen die sogenaamde "kapstokprediking."

Die redevoeringsanalise bied vir die homileet die raamwerk van die sistematiese opbou van die gedagtes waaruit die betrokke skrifgedeelte saamgestel is. Om die skrif "onvoorwaardelik" uit te lê, en om. "kapstokprediking" te vermy moet daar met die struktuur van dię betrokke gedeelte erns gemaak word. Die raamwerk van die gedagtes wat die redevoeringsanalise bied, kan dien as die raamwerk 
waarbinne die "kommentaar"-werk en die "vertaal"-werk geskied. Dit is 'n vraag of die homileet hom hierin moet hou by die gegewe raamwerk in sy sistematiese opbou, en of hy in die prediking daarvan kan afwyk. Wat narratiewe materiaal betref, kan myns insiens die gegewe raamwerk maklik gehandhaaf word. By deskriptiewe materiaal is dit minder maklik, omdat sulke materiaal nie altyd na ons oortuiging sistematies georden is nie.

\section{(c) Die toepassing}

Die betrokke Bybelgedeelte moet in ooreenstemming met sy eie bedoeling tot spreke gebring word in die konkrete situasie van 'n bepaalde gemeente op 'n bepaalde plek en tyd. ${ }^{45}$ Dit kan egter nie geskied alvorens die bedoeling (= skopus) van die gedeelte nie so korrek as moontlik bepaal is nie. Moderne semantiek in sy strukturele arbeid wil hierin te hulp wees.

\section{Slotopmerking}

Die beoefening van homiletiek is van eksegetiese arbeid afhanklik: Dit geld veral wat die prinsipiële besinning daarvan betref. En waar die eksegese-metodeleer al hoe meer die insigte van die moderne taal- en literatuur-wetenskap verdiskonteer, sal hierdie veranderde situasie ook 'n teologiese dissipline soos die homiletiek in 'n meerdere of mindere mate raak.

\section{REFERENCES TO “MODERNE SEMANTIEK"}

$1 \mathrm{~J}$ Barr, The Semantics of Biblical Language, Oxford University Press, 1961.

2 J Barr, Semantics and Biblical Theology - A Contribution to the Discussion, bl 18, artikel gepubliseer in Supplements to Vetus Testamentum, Congress Volume, 22.

3 Vergelyk o a W S Vorster, Moderne linguistiek en Bybelnavorsing, bl 140, artikel gepubliseer in Theologia Evangelica, 1971, vol. 5, no. 2.

4 Vergelyk W S Vorster, Some remarks on contemporary New Testament scholarship methodology and the study of the New Testament, bl 35, artikel gepubliseer in Theologia Evangelica, 1977, vol 10, no. 2 en 3.

5 Vergelyk E Güttgemanns, Die Arbeit geht Weiter!, bl 41-44, artikel gepubliseer in Linguistica Biblica, no. 21-30, 1973.

$6 \mathrm{~W}$ S Vorster, Aischunomai en stamverwante woorde in die Nuwe Testament, ongepubliseerde DD dissertasie, Pretoria, 1974.

7 J A Loader, Aspekte van die begrip "menslike mag" in die Ou Testament, dis Gröningen, 1975.

8 Vergelyk o a die reeds gepubliseerde kongresreferate in Neotestamentica, 8 (1974), onder die titel Linguistics and Bible Translating, asook die tot dusver ongepubliseerde kongresreferate oor die struktuur van Matteus 1;13, 1977.

9 Vergelyk o a die reeds genoemde artikel van W S Vorster, Moderne Linguistiek en Bybelnavorsing, asook A H Snyman, Aspekte van die nuwe benadering tot die semantiek van die Griekse Nuwe Testament, bl 323-334, artikel gepubliseer in Ned Geref Teologiese Tydskrif, deel 16, No. 4, September 1975. 
10 J P Louw, Semantiek van die Nuwe Testamentiese Grieks, Pretoria, 1976.

11 Folker Siegert, Narrative Analyse als Hilfe zur Predigtvorbereitung - ein Beispiel, bl 77-90, artikel gepubliseer in Linguistica Biblica, No. 31-33, 1974.

12 J P Louw, ongepubliseerde diktaatlesing: Inleiding tot die Griekse Taalkunde, bl 2.

13 J P Louw, Inleiding, bl 2-3. Vergelyk ook H C du Toit, ongepubliseerde diktaatlesing: Transformasionele-Generatiewe Grammatika, bl 3.

14 J P Louw, Inleiding, bl 4.

$15 \mathrm{H} \mathrm{C}$ du Toit, Transformasionele-Generatiewe Grammatika, bl 2-3.

$16 \mathrm{~J} P$ Louw, Inleiding, bl 4 en $\mathrm{H} \mathrm{C}$ du Toit, TGG, bl 2.

$17 \mathrm{~J} P$ Louw, Inleiding, bl 5.

$18 \mathrm{~J} P$ Louw, Inleiding, bl 8.

19 Vir kort historiese oorsigte oor die ontwikkellinge op die gebied van die algemene linguistiek sedert De Saussure, vergelyk H C du Toit, TGG, bl 2-16.

$20 \mathrm{H} \mathrm{C}$ du Toit, TGG, bl 17.

21 Vergelyk ] A Loader, a.w., bl 4.

22 J A Loader, a.w., bl 4-5.

23 Vergelyk J P Louw, Inleiding, bl 16-17.

$24 \mathrm{~J} P$ Louw, Inleiding, bl 18.

25 Vergelyk o.a. G M M Pelser, Semantiek en die Vertaling van die Nuwe Testament, bl 1-2, ongepubliseerde rede gelewer by geleentheid van 'n opknappingskursus van predikante van die Nederduitsch Hervormde Kerk van Afrika, 9 April 1975.

$26 \mathrm{~J} \mathrm{H}$ Hospers, Theologie en algemene taalwetenskap, bl 22, artikel gepubliseer in Vox Theologia, 35, 1964/65.

27 Skrywer is egter van mening dat betekenisleer nie suiwer net met sinchroniese fasette van ondersoek te doen moet hê nie. Dit is die gevaar van die moderne linguistiek dat die diachroniese by die semantiek onderskat word. Soos reeds in hierdie studiestuk gesê is: die sinchroniese het die diachroniese materiaal nodig om verskynsels behoorlik te verklaar, maar dan in die regte volgorde: eers sinchronies, dan diachronies. Dit vrywaar teen metodemonisme in die semantiek.

28 A B du Toit, The Significance of Discourse Analysis for New Testament Interpretation and Translation: Introductory Remarks with Special Reference to 1 Peter 1:3-13, bl 55, artikel gepubliseer in Neotestamentica, 8 (1974), onder die titel Linguistics and Bible Translating.

29 Vergelyk J P Louw, Semantiek oan Nuwe Testamentiese Grieks, bl 100. Kursivering deur Louw.

30 Vergelyk G M M Pelser, a.w., bl 4.

31 Die linguistiese beginsel dat 'n woord slegs eenmalig in 'n konteks betekenis het, geld uit die aard van die saak nie in gevalle van doelbewuste dubbelsinnige aanwending van betekenis nie. Skrywer dien voorlopig die opinie dat die verskynsel van reduksie by die wisseling van woorde wat tot dieselfde semantiese woordveld behoort, ook hierdie linguistiese beginsel in sommige kontekste nie toepasbaar maak nie.

$32 \mathrm{~J} \mathrm{H}$ Roberts, Ekklēsia in Acts - Linguistic and Theology: A Venture in Methodology, bl 73-93, artikel gepubliseer in Neotestamentica, 7 (1973), onder die titel Essays on the Gospel of Luke and Acts. Vir 'n meer uitgebreide woordstudie, vergelyk W S Vorster Aischunomai en stamverwante woorde in die Nuwe Testament. ' $n$ Woordstudie moet egter van 'n Begripstudie onderskei word. As 'n voorbeeld van laasgenoemde, vergelyk J A Loader, Aspekte van die begrip menslike mag in die Ou Testament.

33 Vergelyk Report on the Greek New Testament Wordbook for Translators, bl 141-4, artikel gepubliseer in The Bible Translator Vol 24, 1973.

34 A B du Toit, a.w., bl 57.

35 J P Louw, Discourse Analysis and the Greek New Testament, bl 103, artikel gepubliseer in The Bible Translator, vol. 24, No. 1, 1973.

36 Vergelyk W Richter, Exegese als Literaturwissenschaft. Entwurf einer altestestamentlichen Literaturtheorie und Methodologie, bl 50-62, Göttingen, 1971, soos uiteengesit en toegepas deur J A Loader, a.w.

37 Hierdie stap word nie stiptelik volgens die reels van die standaardteorie van die TGG gedoen nie, vanweê die baie tegniese en komplekse aard daarvan. Vir uiteensetting en toepassing van diè reêls, kyk $\mathrm{H} \mathrm{C}$ du Toit, ongepubliseerde diktaatlesing: Transformasionele-Generatiewe Grammatika, 1977, bl 26 e.v. 
38 Vergelyk J I de Wet, ongepulbiseerde diktaatlesing: Die Formele Homiletiek, bl 2.

39 J I de Wet, Formele Homiletiek, bl 10.

40 D J Booysen, Die Keuse van'n Teks vir die Prediking, 'n berig gepubliseer in Die Heroormer, Augustus 1977, bl 4.

41 Geloofsleer vir die Kategese, HAUM Pretoria, 1973, bl 49.

$42 \mathrm{~J}$ I de Wet, Formele Homiletiek, bl 6.

43 J I de Wet, Die dienskarakter van die prediking, bl 109-110 artikel gepubliseer in Heroormde Teologiese Studies, Jaargang 32, af 3 en 4.

$44 \mathrm{~J}$ I de Wet, Formele Homiletiek, bl 7.

45 J I de Wet, Die dienskarakter van die prediking, bl 115. 